\author{
중국 초기 불교사원 배치에 관한 연구 \\ - 후한(後漢)부터 남북조(南北朝)까지의 문헌을 중심으로 -

\section{A Study on the Layout of Early Chinese Buddhist Temples \\ - Focusing on the Literature from the Eastern Han Dynasty to the Northern and \\ Southern Dynasties -} \\ 현 승 욱 \\ Hyun, Seung-Wook \\ (중국 청화대학 건축학원 박사과정)
}

\begin{abstract}
The purpose of this paper is to analyze the layout of Early Chinese Buddhist Temples from the Eastern Han Dynasty to the Northern and Southern Dynasties. The results are as follows:

1) In the Eastern Han Dynasty and Three Kingdoms Period, the layout of Temples was a pagoda-centered system which had one-courtyard. The layout of Temples in this period was still under the influence of Indian Temples.

2) In the Western and Eastern Jin Dynasties, the layout of Temples was still a pagoda-centered system. However, many buildings began to appear in Temples after the mid-4th century. In the Eastern Jin Dynasty, Twin pagodas started to appear in Temples.

3) In the Northern and Southern Dynasties, there were many layout types, but the main form was the layout of front Pagoda and rear Buddhist Hall. The layout of Temples in this period was in a transition stage, which evolved from a pagoda-centered Temple which had one-courtyard and after developed into a Buddhist Hall-centered Temple which had multi-courtyard.
\end{abstract}

주제어 : 중국 초기 불교사원, 불탑중심 배치, 전탑후전 배치

Keywords: Early Chinese Buddhist Temples, The Pagoda-centered Layout, The Layout of front Pagoda and rear Buddhist Hall

\section{1. 서 론}

중국 건축사에서 불교건축은 궁전건축에 버금가는 중 요한 건축유형에 속한다. 하지만 그 중요성에 비하여 현 재 중국 내 불교건축에 관한 연구 성과는 그다지 많지 않다. 기존 연구는 주로 불전, 탑 등의 개별 건축물과 석 굴 등에 집중되어 있으며, 초기 불사배치에 관한 연구는 매우 부족한 실정이다. 이것의 직접적인 원인으로는 궁

* Corresponding Author : hyun521521@hotmail.com

이 연구는 중국 국가자연과학기금(National Natural Science Foundation of China) 지원으로 중국 청화대학 왕귀상(王貴祥) 교수가 주관하는

「5-15세기 고대 중국불교사원 전각배치와 공간구성의 발전과 변화(5-15 世紀古代漢地佛敎寺院內的殿閣配置、空間格局与發展演變)」에 관한 연구임, 과제번호 : 51078220
전, 도성, 능묘건축 등을 발굴의 우선순위에 두고 있는 중국 고고학계의 연구관행을 들 수 있는데, 현재까지 정 식 발굴 보고서나 약보고 형식으로 외부에 알려진 불사 유적이 극히 일부1)라는 점도 이를 증명하고 있다.

중국에서의 중국 초기 불사배치 연구는 숙백(宿白)을 중심으로 이루어졌으며, 이유군(李裕群), 하리군(何利群) 등이 그 연구를 뒷받침하고 있다. 최근에는 왕귀상(王貴 祥) 등이 5- 15 세기 중국 불사 전각배치와 공간구성에 관 한 연구를 진행하고 있다.2)

1) 현재 보고서로 출간되었거나 논문 형식으로 학술지에 발표된 불 사유적은 북위 사원불사(思遠佛寺), 북위 사연불도(思燕佛圖), 북위 영녕사(永寧寺), 동위 - 북제 조팽성불사(趙彭城佛寺), 수 - 당 청룡사 (靑龍寺), 당 서명사(西明寺) 등 대략 6 개소에 불과하다.

2) 숙백의 연구는 宿白, 「東漢魏晋南北朝佛寺布局初探」, 慶祝鄧广 
본 논문은 문헌에 기록된 후한(後漢)부터 남북조(南北 朝)까지의 불사배치에 관한 연구이다. 『위서(魏書)·석로 지(釋老志)』，『낙양가람기(洛陽伽藍記)』，『고승전(高僧 傳)』, 『법원주림(法苑珠林)』 등의 불교관련 문헌과 중 국 사서(史書)에서 보이는 불사에 관한 기록 등을 위주 로 하였고,3) 일부 발굴조사 자료 및 도상(圖像) 자료도 참고하였다.

후한(後漢)에서 남북조(南北朝)에 이르는 본 연구의 시간적인 범위는 불교 및 불교건축의 발전변화에 따라 후한(後漢)-삼국(三國)시기(25-265년)，서진(西晉)-동진 (東晉)시기(265-420년), 남북조(南北朝)시기(420-589년) 의 세 시기로 구분하였다.

\section{2. 후한(後漢) 삼국(三國)의 불사배치}

중국의 불교전래에 관한 여러 학설 가운데, 신뢰할 만 한 것으로는 아래의 2 가지를 들 수 있다.4)

하나는 전한(前漢) 애제 원수원년(기원전 2년)에 박사 제자 경로가 대월지왕의 사자 이존으로부터 입으로 전하 는 불경을 받은 일5)이고, 다른 하나는 후한(後漢) 명제 가 영평 10 년(67년)에 꿈을 꾼 후, 낭중 채음과 박사제자 진경 등을 서역에 보내 불법을 구하여 오게 하고 백마사 (白馬寺)를 세운 일6)이다.

銘教授九十華誕論文集，石家庄：河北教育出版社，1997; 宿白，「隋代 佛寺布局」，考古与文物，1997(02); 宿白，「漢地佛寺布局初探」，梵宮： 中國佛敎建築藝術，上海辭書出版社，2006; 宿白,「試論唐代長安佛敎 寺院的等級問題」, 文物, 2009(01) 등이 있으며, 이유군과 하리군의 연구는 각각 李裕群, 「隋唐以前中國佛敉寺院的空間布局及其演變」, 邊疆民族考古與民族考古學集刊 第一集，文物出版社，2009，何利群， 「北朝至隋唐時期佛敎寺院的考古學研究- - 以塔殿院關係的演變爲中 心」, 石窟寺研究 第1輯, 文物出版社, 2010 등이 대표적이다. 왕귀상 의 연구는 王貴祥, 「佛敎初傳至西晋末十六國時期佛寺建筑概說」, 中國建筑史論匯刊，2012(01)；王貴祥，「東晋及南朝時期南方佛寺建筑 概說」，中國建筑史論匯刊，2012(02); 王貴祥，「隋唐時期佛敎寺院概 覽」, 국립부여문화재연구소 주관 백제문화 기획연구 관련 국제학술 회의, 2012년 9월 19일 등이 있다.

3) 본 연구에 사용된 불교관련 문헌은 상술한 선행연구에서 대부분 인용하였으나, 중화서국(中華書局)의 원문과 대조작업을 거쳤으며, 본문의 서술방향에 따라 가감하였음을 밝혀둔다. 참조한 원문은 아 래와 같다. [晋]陳壽 撰 栗本夫 武彰 譯、『三國志』, 北京 : 中華書 局, 2009 ; [ 北魏]楊街之 撰 周租謨 校譯, 『洛陽伽藍記校譯』2版, 北 京：中華書局, 2010 ; [北魏]䧢道元 著 陳橋驛 校證, 『水經注校證』, 北京：中華書局, 2007 ; [梁]慧挍 撰 湯用彤 校注, 『高僧傳』, 北京： 中華書局，1992；[北齊]魏收，『魏書』，北京：中華書局，1974；[唐] 釋道世 撰 周叔迦 蘇普仁 校注, 『法苑珠林校注』, 北京：中華書局, 2006 ； [唐]張彦遠, 『歷代名畫記』, 北京：中華書局, 1985 등등

4）宿白,「漢地佛寺布局初探」，梵宮：中國佛敎建築藝術，上海辭書出 版社, 2006, p2

5）『三國志·魏志·烏丸鮮卑東夷傳裴注』，“昔漢哀帝元壽元年，博士弟 子景盧受大月氏王使伊存口授浮屠經”

6)『魏書·釋老志』, “帝遣郎中蔡愔博士弟子秦景等使於天竺，寫浮屠遺
전자의 기록에는 건축적인 사항이 없으나, 후자는 아 래와 같은 기록을 통하여 당시 신도들이 불탑을 중심으 로 하여 신앙활동이 이루어졌음을 알 수 있다.

이 때 낙양성 서옹문 밖에 불사[불탑]를 세웠는데, 그 벽에는 수천 수만의 신도들이 탑 주위를 3겹으로 둘러 싸고 있는 그림이 있었다. ${ }^{7}$

여기에서 말하는 불사가 바로 백마사이며, 당시 불사 는 곧 불탑을 의미하는 것이었다. 이 백마사 탑은 『위 서·석로지』에 더욱 자세하게 묘사되어 있다.

낙양에 백마사를 세운 이래로, 성대하게 장식한 탑[佛 [圖과 탑에 그린 오묘한 그림은 전국 각지 탑의 본보기 가 되었다. 무릇 궁탑제도(宮塔制度)는 천축의 옛 모습 에 의거하였기 때문에 중층이며 1 층에서 $3,5,7,9$ 층에 까지 이른다. 세상 사람들이 이를 서로 이어받아 부도 (浮圖) 또는 불도(佛圖)라 불렀다.8)

이와 같이, 낙양 백마사는 부도(浮圖) 또는 불도(佛圖) 라 불리는 불탑이 중심인 불사였는데, 이러한 형식은 천 축의 제도(制度)를 모방한 것이었다. 이 탑이 전국 각지 의 본보기가 되었다는 것은 곧 전국 각지에 이와 유사한 불탑중심의 불사가 세워졌다는 것을 의미한다.

그 후, 후한 헌제 초평년간(190-193년)에 착융(笮融) 이 부도사(浮圖祠)를 건립하였다. 이에 관한 기록은 『삼국지·오지·류요전』과 『후한서·도겸전』에서 각각 나타나며, 다음과 같다.

착융은 단양사람이다. 처음 수백명을 모아 서주목 도겸 에게 가서 의탁하였다. 도겸이 그에게 광릉, 단양의 물 자를 배로 실어 나르는 일을 감독하도록 하였는데, 마 침내 그는 방종하고 사람을 함부로 죽였다. 그리고 3군 의 조운을 끊어 자기에게로 돌리고, 이에 부도사(浮圖 祠)를 크게 세웠다. 동으로 사람을 만들어 황금을 몸에 칠하고 화려한 비단을 입혔다. 동반(銅盤)은 9겹으로 늘 어뜨렸고, 그 아래는 중루(重樓)였으며, 각도(閣道)에는 삼천여 명을 수용할 수 있었다.9)

范. 愔仍與沙門攝摩䲲竺法蘭東還洛陽 …… 愔之還也, 以白馬負經而 至，漢因立白馬寺於洛陽雍門西”

7）『弘明集』卷一「理惑論」, “時於洛陽城西雍門外起佛寺, 於其壁畫 千乘萬騎繞塔三匝”

8）『魏書·釋老志』, “自洛中構白馬寺, 盛飾佛圖, 畫迹甚妙, 爲四方式. 凡宮塔制度, 犹依天竺舊狀而重構之, 從一級至三五七九. 世人相承, 謂 之浮圖, 或云佛圖”

9）『三國志·吳志·劉蓀傳』，“笮融者，丹陽人。初聚衆數百，往依徐州牧 陶謙. 謙使督廣陵, 丹陽運漕, 逐放縱擅殺, 坐斷三郡委輸以自入, 乃大 起浮圖祠. 以銅爲人, 黃金涂身, 衣以錦採. 垂銅盤九重, 下爲重樓. 閣 
같은 군의 착융이란 자가 수백명을 모아 도겸에게 가서 의탁하였다. 도겸은 착융에게 광릉, 하비, 팽성의 식량 운송 감독을 맡겼다. 마침내 그는 3군에서 운송된 것을 끊고, 부도사(浮圖寺)를 크게 세웠다. 위는 금반(金盤)을 포개었고, 아래는 중루(重樓)였다. 또 당각(堂閣)으로 주 위를 둘렀는데, 삼천여 명을 수용할 수 있었다. 황금을 칠한 상을 만들고 화려한 비단을 입혔다.10)

위의 두 기록은 몇 가지 단어의 쓰임이 서로 다를 뿐, 그 내용은 거의 일치한다. 부도사(浮圖祠 또는 浮圖寺) 라는 절 이름에서 알 수 있듯이 이 절은 부도(浮圖), 즉 탑이 중심인 불사였다. 여기에는 탑[浮圖]과 각도(또는 당각)가 기록되어 있다. 탑은 ‘垂銅盤九重, 下蒍重樓”, “上累金盤, 下爲重樓”로 각각 표현되었는데, 동반(또는 금반)은 탑상부의 보륜(寶輪)을 가리키는 것으로 인도 스투파를 상징하며, 중루(重樓)는 중국 고대건축의 중층 목조 누각을 말하는 것이다. 따라서, 이 탑은 상부의 인 도 스투파 요소와 하부의 중국 전통건축 요소가 결합되 어 탄생된 최초의 중국식 불탑이었다.11) 그리고 각도(또 는 당각)는 탑 주위를 둘러싼 회랑형식의 건물을 의미하 는데, 삼천 여명을 수용할 수 있는 큰 규모였다.

이와 같은 불사형태는 삼국시기 위(魏)의 불사에서도 찾을 수 있다.

위(魏) 명제(227-240년 재위)는 일찍이 궁전 서쪽의 탑 [佛圖]을 허물고자 하였다. 이에 외국 승려가 금반에 물 을 담아 불전 앞에 놓고 불사리를 물에 던졌다. 이에 오색 빛이 발하니, 황제가 감탄하여 말하기를, '만일 영 험한 것이 아니라면 어찌 그러할 수 있겠는가?'라고 하 였다. 마침내 탑을 길의 동편으로 옮기고, 주각(周閣) 100 칸을 지었다. 그리고 원래 탑이 있던 자리에 몽범지 (濛氾池)를 만들고, 가운데 연꽃을 심었다. ${ }^{12)}$

위의 불사 역시 탑[佛圖]과 주각(周閣)으로 구성되었 는데, 여기의 주각은 상술한 각도(또는 당각)의 다른 표 현이다. 이제까지 살펴본 후한, 삼국의 불사 3 개소는 모

道可容三千余人”

10）『後漢書·陶謙傳』, “同郡人笮融, 聚衆數百, 往依於謙. 謙使督廣陵 下丕彭城運糧, 逐斷三郡委輪, 大起浮圖寺. 上累金盤, 下爲重樓. 又堂 閣周回, 可容三千許人. 作黃金塗像, 衣以錦綵”

11）梁思成, 「中國的佛教建築」，淸華大學學報(自然科學版)，1961年 02期, p52

12）『魏書·䆁老志』，“魏明帝篔欲壞宮西佛圖。外國沙門乃金盤盛水， 置於殿前，以佛舍利投之於水，乃有五色光起，於是帝歎日，自非靈異， 安得爾乎。遂徙於道東, 爲作周閣百間. 佛圖故處, 鏭爲濛氾池, 種芙蓉 於中”
두 중심 탑과 탑 주위의 회랑식 건물로 구성되는데, 이 는 문헌을 통해 확인할 수 있는 중국 최초의 불사형식이 다. 이 형식의 기원에 대하여는 크게 두 가지 견해가 있 는데,13) 하나는 한대(漢代) 예제건축(禮制建築)이고, 다 른 하나는 한대 이래로 나타나는 중층 목조 고루(高樓) 이다.

전한(前漢) 장안성 남쪽교외에서 발굴된 중국 고대 예 제건축은 상술한 불사형식과 유사한 배치를 보인다. 이 유적은 원락 중앙의 중심건축과 원형수로, 방형 담장, 4 면의 문과 4 면 모서리각의 그자 건물 등의 부속건축으로 이루어져 있다. 정방형 원락은 한 변이 약 235미터에 달 하며, 그 중앙의 중심건축은 \zh21ㅣㅈㅏ 평면으로 전체 너비가 약 24 미터이다.14)<Fig.1> 이는 상술한 불사형식에 비해 매우 큰 규모이기는 하나, 공간의 구성원리는 일치하는 것이다. 왕귀상(王貴祥)은 예제건축에서 4면에 문을 낸 것을 근거로 하여, 당시 불사의 회랑식 건물 4 면에도 문 이 있었을 것으로 추정하였다. ${ }^{15)}$

한대(漢代) 이래로 통치계급 저택에 세웠던 중층 목조 고루의 형태도 상술한 불사형식과 매우 유사하다. 한대 무덤에서 출토된 명기(明器)를 통해 그 입체적인 모습을 파악할 수 있는데, 대표적인 예로 감숙성 무위(武威) 뇌 대한묘(雷臺漢墓)에서 출토된 유도조루원(釉陶碉樓院)과 호북성 양번(襄樊) 채월삼국묘(菜越三國墓)에서 출토된 상륜도루(相輪陶樓)를 들 수 있다.

유도조루원(釉陶碉樓院)은 원락 중앙의 5층 누각과 방 형 담장, 담장 위의 2 층 문루 및 각루, 이들을 잇는 공중 다리[飛栈]로 구성되어 있다.16)<Fig.2> 그리고 원락 내

13) 부희년(傅喜年), 왕귀상(王貴祥) 등은 중국 고대 예제건축을 그 기원으로 보았다. 양사성(梁思成)은 “신선은 누대(樓臺)에 머무는 것 을 좋아한다(仙人好樓居)”(『史記·封樿書』)는 중국 전통사상을 근 거로 하여, 당시 중층 누각(누대)에 외래에서 온 신선인 부처를 모 셨을 것으로 추정하였다. 숙백(宿白)은 여기에 한대(漢代) 화상석, 화상전, 명기 등의 도상(圖像) 자료를 보충하여 양사성의 주장을 뒷 받침하였으며, 이유군(李裕群), 나세평(羅世本) 등은 숙백의 연구를 뒷따르고 있다. 김성우는 이 두 가지를 모두 언급하였다. (傅喜年 主編, 『中國古代建築史 第2卷 三國兩晉南北朝隋唐五代建築』2版, 中國建築工業出版社, 2009, p188; 梁思成, 「中國的佛呚建築」, 清華大 學學報(自然科學版)，1961年02期，p52；王貴祥，「隋唐時期佛敎寺院概 覽」, 국립부여문화재연구소 주관 백제문화 기획연구 관련 국제학술 회의, 2012년 9월 19일; 宿白,「漢地佛寺布局初探」, 梵宮: 中國佛敎 建築藝術，上海辭書出版社，2006; 李裕群，「隋唐以前中國佛敎寺院的 空間布局及其演變」，邊疆民族考古與民族考古學集刊 第一集，文物出 版社, 2009; 羅世本, 仙人好樓居: 襄陽新出相輪陶樓與中國浮圖祠類登, 故宮博物院院刊, 2012(4); 김성우, 「동아시아 불사의 최초 형식」, 대한건축학회 논문집 3권 3호, 1987 참조)

14）唐金裕,「西漢西郊漢代建築遺址發掘報告」，考古學報, 1959(02)

15）王貴祥, 「隋唐時期佛敉寺院概覽」, 국립부여문화재연구소 주관 백제문화 기획연구 관련 국제학술회의, 2012년 9월 19일

16）甘肅省文物局，『甘肅文物菩華』，北京，文物出版社，2006, p37 
부의 정면을 제외한 3 면에 협벽(夾壁)을 세웠는데, 이 협 벽과 담장 사이의 공간은 상술한 불사의 회랑식 건물과 매우 유사한 공간이다.

상륜도루(相輪陶樓)는 원락 중앙의 2 층 누각과 정면 문루 및 정면을 제외한 3 면의 담장으로 구성되어있다. 17)<Fig.3> 비록 여기에는 회랑식 건물이 없으나, 2 층 누각의 지붕 위의 보륜과 중루(重樓)가 결합된 형식은 착융 부도사탑의 문헌기록과 거의 일치하는 것이다.

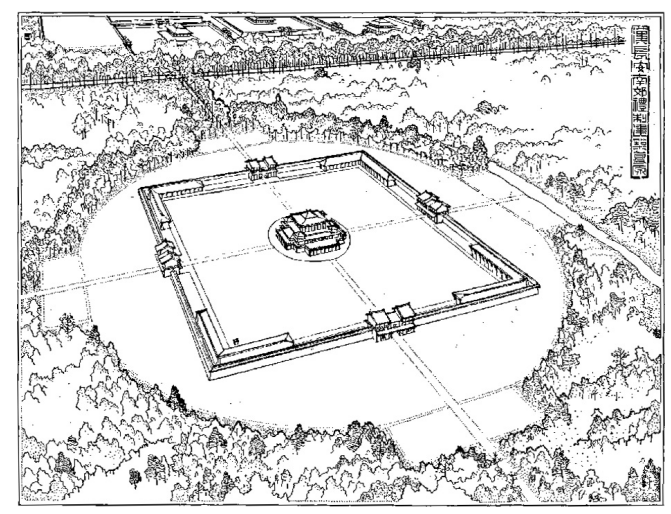

Fig.1 The restoration drawing of the Han Ritual Architecture (Source: References 14)

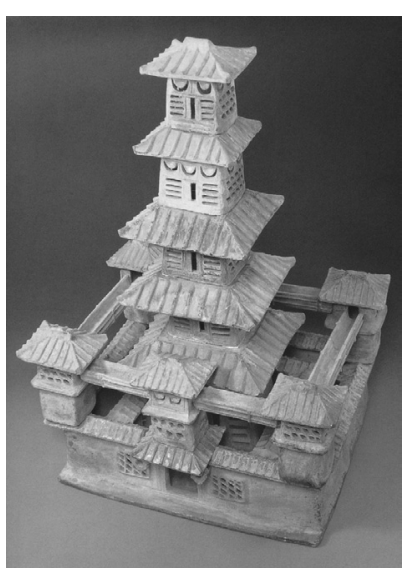

Fig.2 Glazed pottery yard with watch tower (Source: References 19, p37)

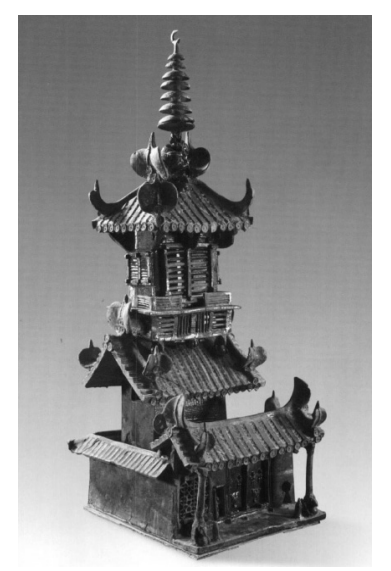

Fig.3 Xianglun(相輪) pottery tower (Source: References 25, p8)

\section{3. 서진(西晉) 동진(東晉)의 불사배치}

서진, 동진에 이르러 불교는 통치계급의 지지와 보호 아래 크게 발전하기 시작하였고, 이로 인해 불사와 신도 수, 그리고 불사 내 건축물이 점차 증가하였다.

17）襄牀市文物考古研究所，「湖北襄牀牀城菜越三國墓發掘簡報」，文 物, 2010, 第9期, p19 20
(도안(道安)이) 다시 사찰을 세웠는데, 이름은 단계사(檀 溪寺)로, 청하 장은(張殷)의 저택이었다. 큰 부자가 찬조 하여 5층 탑을 세우고, 건물 400 칸을 지었다. ${ }^{18)}$

동진 흥녕3년(365년)에 도안이 세운 단계사는 5 층 탑 이외에 400여칸 규모의 건물이 있었다. 단, 이 기록에서 는 건물의 구체적인 사항은 명확하게 나타나지 않는다. 그 후, 도안의 제자 혜영(惠永)과 혜원(慧遠)이 여산에 정사(精舍)를 세우고 건물을 지었는데, 각각 다음과 같 다.

동진(東晉) 태화년간(366-371년)에 심양 여산 북쪽 고개 아래에 사묘(寺廟)를 세웠다. ...... 남쪽 고개 위로 가서 방우(房宇)를 짓고, 당전(堂殿)을 세웠다. 안개와 노을이 서로 교차하여 능운정사(凌雲精舍)라 이름하였다. ${ }^{19)}$

전진(前秦) 건원9년(373년)에 진(秦)나라 장군 부비(符丕) 가 양양으로 진공하였다. ….. (칙사) 환이(桓伊)가 혜원 을 다시 산의 동쪽으로 보내 방전(房殿)을 세우도록 하 였는데, 이는 곧 동림사(東林寺)이다. ….. (혜원이) 절 로 돌아와서 절 내에 따로 선림(禪林)을 세우고 ...... 감 실(龕室)을 지었다.20)

이와 같이, 4 세기 중반 이후부터 불사 내에 방우(房 宇), 당전(堂殿), 방전(房殿), 감실(俞室) 등의 다양한 건 축 요소가 등장하였다. 이러한 변화는 4세기 말, 북위(北 魏) 천흥원년(398년)에 평성(平城)에 세워진 불사로 이어 진다.

천흥원년(398년)에 조서를 내렸다. '..... 이에 유사에게 명하니, 경성(京城)에 불상[容范]을 만들어 꾸미고, 궁사 (宮舍)를 고쳐 지어, 믿고 따르는 무리들에게 거처를 제 공하도록 하라.' 이 해에 5층 탑[佛圖], 기도굴산(老闍崛 山) 및 수미산전(須彌山殿)을 짓고, 채색장식을 더하였 다. 그 밖에 강당(講堂), 선당(禪堂) 및 사문좌(沙門座)를 지었는데 장엄하게 갖추지 않은 데가 없었다.21)

18）『高貨傳』卷五「道安傳」, “更立寺名日檀溪, 師清河張殷宅也. 大 富長者米加贊助，建塔五層起房四百”

19）『名僧傳抄』「惠永傳」, “以晉太和中, 於尋陽盧山北岭下, 創立寺 廟 ……移於南岭之上, 築莫房宇構起堂殿. 与烟霞交接, 名日凌云精 舍”

20）『高僧傳』卷六「慧遠傳」, “僞秦建元九年, 秦將符不, 寇升衰陽 ……桓乃爲遠復於山東更立房殿, 節東林是也. ……復於寺內別置禪 林 …… 營築弇室”

21）『魏書·䆁老志』, “天興元年, 下詔曰 ……其敕有司, 於京城建飾 容范, 修整宮舍, 令信向之徒, 有所居止. 是歲, 始作五級佛圖者闍崛山 及須弥山殿, 加以繢飾. 別构講堂禪堂及沙門座, 莫不嚴具焉” 
이는 중국 문헌에서 최초로 보이는, 완정(完整)한 배 치를 갖춘 불사의 기록이다. 물론, 문자의 한계로 인해 구체적인 배치는 확인할 수 없으나, 왕귀상(王貴祥)은 이 를 탑, 불전, 강당, 선당, 승방(사문좌)이 중축선을 따라 차례로 배치된 것으로 추정하였다.22) 이 불사가 북위황 실이 평성으로 천도하여 궁궐 등과 함께 초창(初創)한 황실불사였다는 점에서 상술한 추정은 가능성이 높아 보 인다.

한편, 동진 시기에는 불사 내 쌍탑이 출현하였는데, 이 는 중국 문헌에서 보이는 가장 이른 예이다. 창락사(昌 樂寺)와 장간사(長干寺)의 쌍탑에 관한 기록은 다음과 같다.

(왕이(王㢞)는) 원제(317-322년 재위) 때에 좌위장군을 맡았고, 무강후에 봉해졌다. 이 때에 진군 사상(謝尙)이 무창 창락사(昌樂寺)에 지은 동탑과 대약사(戴若思)가 지은 서탑에 왕이를 청하여 그림을 그리게 하였다.23)

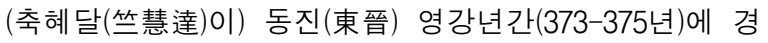
사(京師)에 이르렀다. 먼저, 간문황제(371-372년 재위)가 장간사(長干寺)에 삼층탑을 세웠는데, 탑이 완성된 후 매일 저녁 빛이 발하였다. 월성(越城)에 올라 바라보니 $\ldots . .$. 밤에 탑[刹] 아래 빛이 나타났다. $\cdots . .$. 이에 옛 탑 의 서쪽에 다시 탑[刹]을 세우고 사리를 안장하였다. 동 진 태원16년(391년)에 효무가 다시 3층을 더하였다.24)

이와 같이, 창락사와 장간사의 동, 서탑은 동시에 세워 진 것이 아니라 시간차를 두고 건립되었는데, 이것이 당 시 체계적인 불사계획에 의한 것인지, 우연한 결과의 산 물인지는 정확하게 알 수 없다. 하지만, 불사 내 동편과 서편에 탑이 세워졌던 것은 분명한 사실로 여겨지며, 이 는 곧 4 세기 중반이후 불사 내 다양한 건축요소의 출현 을 반영하는 것이라고 생각된다.

\section{4. 남북조(南北朝)의 불사배치}

남북조시기에는 4 세기 중반 이후에 시작된 불사 내 건 축물의 증가 및 배치의 다양화가 본격적으로 진행되어,

22) 王貴祥, 「隋唐時期佛敉寺院概覽」, 국립부여문화재연구소 주관 백제문화 기획연구 관련 국제학술회의, 2012년 9월 19일

23）『歷代名畫記』卷五「王庴」, “元帝時爲左衛將軍，封武康侯，時鎮 軍謝向於武昌昌樂寺造東塔, 戴若思造西塔, 并請廝畫”

24）『高僧傳』卷十三「竺慧達傳」，“(竺慧達)晉寧康中至京師。先是， 簡文皇帝於長干寺造三層塔，塔成之後，每夕放光 ……夜見刹下時有 光出 …… 万於舊塔之西, 更竪一刹, 施安舍利. 晉太元十六年孝武更加 爲三層”
여러 형태의 불사배치가 나타났다. ${ }^{25)}$ 그 가운데 전탑후 전(前塔後殿) 또는 전탑후당(前塔後堂)26)의 배치가 가장 두드러졌다.

송(宋) 원가 10 년(433년), 종산(鍾山)의 양지에 머물 곳을 정하여, 무성한 초목을 베어내고 정사(精舍)를 지었다. 높은 탑[刹]이 구름에 닿았고, 높은 당(堂)이 해 아래 있 었다.27)

두타사(頭陀寺)는 승려 석혜종(釋慧宗)이 세웠다. …..... 송(宋) 대명5년(461년) 방장(方丈)을 세우고 띠로 지붕을 이어 불경과 불상을 덮었다. $\cdots \cdots$ 안서장군 영주자사 강안백 제양 사군 채흥종(蔡興宗)은 기단을 높이고 탑 [表刹]을 세웠으며, 선송지당(禪誦之堂)을 지었다.28)

위의 기록은 남조 송대(宋代) 불사(정사)를 묘사한 것 이다. 탑을 먼저 언급한 다음 당을 말한 것으로 보아, 전 탑후당 배치였을 것으로 추정 가능하나, 확실한 근거는 없다. 하지만 이후의 문헌에서 탑과 전(당)의 전후 방위 가 분명하게 나타나며 다음과 같다.

전 앞의 탑은 송(宋) 초왕 의계(義季)가 만들었고, 탑 안 의 소상(素像)은 도리천(㣼利天) 장인이 만들었다.29)

(담속(量俗) 법사가) 양(梁) 대동3년(537년)에 이 지역에 이르렀다. ….. 법사가 신비한 영험을 얻어 절을 확장 하고자 하였다. 이에 전 앞에 수미지탑(須彌之塔)을 세 우니, 성력(盛力)으로 인하여 신도들이 모여들었다.30)

25 ) 왕귀상(王貴祥)은 남북조에서 수대(隋代)에 이르는 불사배치를 불탑중심, 전탑후전(前塔後殿), 전전후당(前殿後堂), 전탑후당(前塔後 堂), 탑-전-당 배치, 일정이배(一正二配), 일각이루(一閣二樓), 남각 북탑(南閣北塔), 일전쌍탑(一殿雙塔) 등으로 구분하였다.(王貴祥, 「陏 唐時期佛敉寺院概覽」, 국립부여문화재연구소 주관 백제문화 기획연 구 관련 국제학술회의, 2012년 9월 19일) 이와 같이, 이 시기에는 여러 배치형태가 보이지만, 배치의 기본요소는 탑과 전(당)이었다. 따라서 전탑후전 또는 전탑후당 형식이 가장 많이 나타났으며, 여기 에 탑이나 부속건축이 가감되어 다양한 배치형태를 이루게 된 것이 다.

26) 남북조시기 남조불교는 현학의리(玄學義理)를, 북조불교는 종교 행위(宗教行爲)를 각각 우선시하였다. 이는 곧 불사 건축에도 영향 을 끼쳐, 남조불사에서는 강당(講堂)을, 북조불사에서는 불전(佛殿) 을 중요시하게 되었고, 이에 따라 남조불사에서는 전탑후전을 대신 하여 전탑후당 배치도 많이 사용하였다.

27）『名僧傳抄』名僧傳第十九「僧伽羅多囉」, “以元嘉十年, 卜居鐘山 之陽, 剪開榛芙, 造立精舍. 篮刹陵云, 高堂架日”

28）『文選』卷五十九「頭陀寺碑文」, “頭陀寺者, 沙門釋慧宗之所立也 ……宋大明五年, 始立方丈茅茨, 以庇經像 ……安西將軍趴州刺史江 安伯濟陽蔡使君諱興宗, 復爲崇基表刹, 立禪誦之堂焉”

29『法苑珠林』卷三十九「感應緣 總述中邊化迹降灵記」, “殿前塔, 宋譙王義季所造. 塔內素像, 㣼利天工所造”

30）『全唐文』卷一百八十四「广州寶莊嚴寺舍利塔碑」, “說大同三歲, 
도인사(導因寺)는 오늘날의 천황사(天皇寺)이다. 백전(柏 殿) 5 칸 및 협전[兩厦]이 있는데, 양(梁) 우군장군 장승요 (張僧猺)가 벽화를 그렸다. ……전 앞에 오층탑 역시 빛이 났다. ${ }^{31)}$

위의 기록은 각각 남조 송대의 형주 하동사(河東寺)와 남조 양대의 광주 보장엄사(寶莊嚴寺), 형주 도인사(導因 寺)를 묘사한 것으로, 모두 불전 앞에 탑을 세운 전탑후 전 배치를 보이고 있다. 한편, 북조의 전탑후전 배치는 일련의 북위(北魏) 불사를 통하여 확인할 수 있다.

그 해(465년)에 고조가 태어났다. 이때 영녕사(永寧寺)를 세우고 7층 탑[佛圖]을 만들었는데, 높이는 300여 척이 고 기단과 세워진 목구조가 거대하여 천하의 제일이었 다.32)

이는 북위 평성 영녕사에 대한 기록으로, 불전에 대한 언급이 없는 것으로 보아 불탑중심 배치로 볼 수 있 다.33) 평성 영녕사가 건립된 지 14 년 후, 평성 북쪽 방산 (万山)에 사원불사(思遠佛寺)가 세워졌다.

(태화3년(479년) 8월) 을해(乙亥)에 방산을 둘러보고 사 원불사(思遠佛寺)를 세웠다.34)

(방산) 산맥 위에 문명태황태후(文明太皇太后)의 능(陵) 이 있고, 능의 동북쪽에는 고조의 능이 있다. $\cdots . .$. 원 바깥 서쪽에 사원영도(思遠靈圖)가 있다.35)

이와 같이, 사원불사(또는 사원영도)는 북위 문명태황 태후 풍씨릉원(馮氏陵園) 안에 세워진 황실불사였다. 문

届於茲邑 ……法師聿提神足, 愿啓規模. 爱於殿前, 更須弥之塔, 因緣 盛力, 人以子來”

31）『續高僧傳』卷三十三「荊州內華寺釋慧耀傳」, “昔日導因, 今天皇 寺是也. 見有柏殿五間兩厦. 梁右軍將軍張僧瑤, 自筆圖畫 ……殿前五. 級亦放光明”

32）『魏書·䆁老志』, “其歲, 高祖誕載. 於時起永寧寺, 構七級佛圖, 高 三百餘尺, 基架博敞, 営天下第一”

33) 이에 대하여 이유군(李裕群)은 "(낙양 영녕사는) 평성 7 층탑의 수법을 취하여 또 높고 크게 만들었다(取法代都七級, 而又高廣之)." (『水經注』卷十六「谷水」)라는 구절을 근거로 하여, 평성 영녕사 역시 낙양 영녕사와 마찬가지로 전탑후전의 배치였을 것으로 추정 하였다. (李裕群, 「隋唐以前中國佛敉寺院的空間布局及其演變」, 邊疆 民族考古與民族考古學集刊 第一集，北京，文物出版社，2009，p295 참 조)

34）『魏書·高租紀上』, “(太和三年八月)乙亥, 幸方山, 起思遠佛寺”

35）『水經注』卷十三「潈水」, “岭上有文明太皇太后陵, 陵之東北有高 祖陵 ……院外西側, 有思遠靈圖”
헌을 통해서는 그 배치를 알 수 없으나, 발굴을 통하여 전탑후전 배치임이 확인되었다. 발굴보고서에 따르면, 전 체 사원은 남향의 장방형 평면으로 상하 2 층의 기단이 있다. 1 층 기단은 남북 87.8 미터, 동서 57.4 미터의 장방형 이며, 기단 남쪽에는 답도가 있다. 2층 기단은 남북 45.8 미터, 동서 35미터의 장방형이며, 역시 남쪽에 답도가 있 다. 2 층 기단 위에는 중축선을 따라 문지, 탑지, 불전지, 승방지가 차례로 발견되었다. ${ }^{36)<F i g .4>~}$

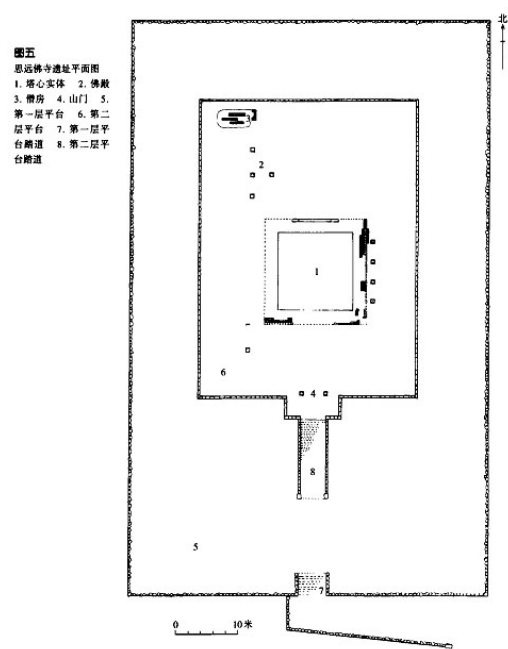

Fig.4 Siyun Temple (思遠佛寺) Site (Source: References 20, p7)

사원불사 건립 이후, 풍태후(馮太后)는 고국 북연(北 燕)의 용성(龍城)에 사연불도(思燕佛圖)를 건립하였다. 이 역시 발굴을 통하여 그 배치가 확인되었다. 발굴보고 서에 따르면, 사연불도는 당시 폐허였던 삼연궁전(三燕 宮殿) 터에 세워졌으며, 북위 태화9년(485년)에서 태화14 년(490년) 사이에 건립된 것으로 추정된다. 중심 탑지와 그 주위를 둘러싸고 있는 회랑 건물지가 발견되었다. 탑 지는 정면 7 칸, 한 변의 너비가 약 18.9 미터인 정방형 평 면이며, 주초 및 주초흔적 64개가 중심에서 바깥으로 4 겹으로 둘러져 있다. 회랑 건물지는 탑 주위를 둘러싸고 있는데 정면은 11 칸으로 약48.6미터이고, 측면은 2 칸으로 약 5.8미터이다.37)

사연불도의 배치는 앞서 살펴본 후한, 삼국의 불사배 치와 매우 유사하며, 발굴보고서에서도 이와 같이 기록 하고 있다. 하지만 보고서 말미에서, 추가 탐사결과 탑의 사방 50여 미터 지점에서 벽체흔적이 발견된 점, 그리고

36）大同市博物館, 「大同北魏方山思遠佛寺遺址發掘報告」, 文物, 2007年 第4期, p4 8

37）遼寧省文物考古研究所 朝陽市北塔博物館, 「朝陽北塔 考古發掘與 維修工程報告」，文物出版社，2007，p26 29 
탑의 북쪽 10 여 미터 지점에 항토기초가 발견된 점 등으 로 미루어 다른 배치형태일 가능성도 열어 두고 있다.38) 만일 이것이 전체 사원의 담장과 탑 북쪽의 불전지라면, 사연불도는 사원불사와 마찬가지인 전탑후전 형식으로 보는 것이 타당하며, 또 사원불사와의 밀접한 연관성을 고려해본다면 그 가능성은 더욱 높다. ${ }^{39)}$

그 후 북위황실은 낙양으로 천도하여(494년), 516년에 낙양 최대의 불사인 영녕사(永寧寺)를 세웠다.

영녕사는 희평원년(516년) 영태후 호씨가 세웠다. …... 절 안에는 9층 탑[浮圖] 하나가 있는데, 목구조이며, 높 이는 90 장이다. 위에 높이 10장의 금찰(金刹)이 있어, 전 체 탑의 높이는 1000 척이다. ….. 탑[浮圖] 은 4면으로 되어있고, 한 면에는 3 개 문과 6 개 창이 있는데, 문은 모두 붉게 칠하였다. ….. 탑[浮圖]의 북쪽에는 불전 하 나가 있는데, 형태가 태극전(太極殿)과 같다. $\cdots \cdots$ 승방 (僧房)과 누관(樓觀)이 천여 칸이다. $\cdots . .$. 사원 담장은 모두 짧은 서까래를 깔고 기와로 덮었는데 오늘날 궁전 담장과 같다. (사원 담장의) 4면에는 각각 문을 하나씩 내었다. 남문루는 삼층이고, 세 갈래의 각도(閣道)가 통 하고 있다. 높이는 20장이고 형태는 오늘날 단문(端門) 과 같다. $\cdots \cdots$ 동서 양문은 모두 이와 같은데 2층이라 는 것만이 다르다. 북문에는 하나의 길이 있으며, 위에 는 건물을 세우지 않아, 마치 오두문(烏頭門)과 같았다. $\ldots . .$. 영희3년(534년) 2월, 탑[浮圖]이 불탔다.40)

『낙양가람기』의 자세한 묘사는 발굴을 통해서 일부 확인되었다. 발굴보고서에 따르면, 전체 평면은 남북 301 미터, 동서 $212 \mathrm{~m}$ 의 장방형으로, 사방에 담장을 둘렀으며, 북쪽을 제외한 3 면의 문지가 발견되었다. 목탑지는 사원 중심에서 약간 남쪽으로 치우진 곳에 위치하며, 정방형 평면이다. 지하와 지상으로 나뉘는데, 지하부분은 항토기 초로 한 변이 약 100 여 미터인 정방형이며, 지상부분은 목탑의 항토기단으로 한 변이 약 38 여 미터인 정방형이 다. 항토기단 위에는 5 겹으로 둘러싸인 124 개의 주초가 발견되었다. 또 탑지 북쪽으로 불전지가 발견되었는데, 훼손이 매우 심하여 지하 기초만을 대략 확인할 수 있었

38）遼寧省文物考古研究所 朝陽市北塔博物館, 「朝陽北塔 考古發掘與 維修工程報告」，文物出版社，2007，p126 133

39) 하리군(何利群)도 그의 논문에서 이와 같은 가능성을 언급하고 있다. (何利群, 「北朝至隋唐時期佛敉寺院的考古學研究 以塔殿院關係 的演變爲中心」, 石窟寺研究 第1輯, 文物出版社, 2010, p183 참조)

40）『洛陽伽藍記』卷一「永寧寺」，“永寧寺，熙平元年，靈太后胡氏 所立也 ……中有九層浮圖一所, 架木爲之, 擧高九十丈. 有刹復高十 丈, 合去地一千尺 ……浮圖有四面, 面有三戶六窗, 戶皆朱漆 ……浮 圖北有佛殿一所, 形如太极殿 ……僧房樓觀一千餘間 ……寺院墙皆 施短橡, 以瓦覆之, 若今宮墙也. 四面各開一門. 南門樓三重, 通三閣道, 去地二十丈, 形制似今端門 ……東西兩門亦皆如之. 所可異者, 唯樓二 重. 北門一道不施屋, 似烏頭門 …… 永熙三年二月, 浮圖㟶火所燒”
으며, 『낙양가람기』에 나오는 천여 칸의 승방과 누관 유적은 발견되지 않았다. ${ }^{41)<\text { Fig.5 }>}$

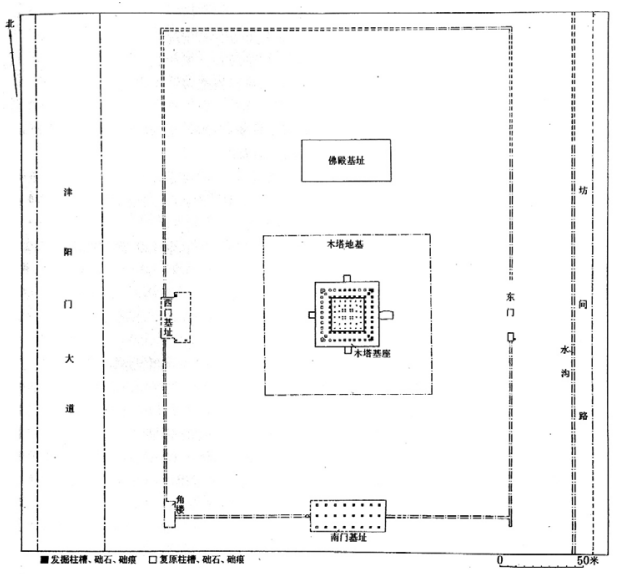

Fig.5 Yongning Temple (永寧寺) Site (Source: References 16, p7)

한편, 남북조 말기에 이르러 다원식(多院式) 대형불사 가 처음으로 출현하였다.

중원(中院)에서 대문까지는 7리나 되었고, 낭무(廊廡)가 서로 솟아있고 처마가 잇닿아 있었다. 옆에는 36 개소 원락을 세웠는데 모두 못과 대(臺)가 있고, 주우(周宇)로 둘러싸여 있었다. 천여 명의 승려가 사사공양을 하였 다. ${ }^{42)}$

사방(寺房)은 5중(五重)이고, 모두 측면이 7가(七架)이다. 크고 작은 별원(別院)이 10개소 있는데, 반야(般若), 방 등(方等)의 두 원이 가장 장엄하여, 여름 안거 때는 항 상 천명이 상주하였다. 절 안에 방우(房宇) 및 사방에 두른 낭무(廊無)가 모두 만 칸이다.43)

전자는 남조 양대(梁代) 불사인 대애경사(大愛敬寺)를, 후자는 형주 하동사(河東寺)의 양대 및 그 이후 상황을 각각 묘사한 것이다. 이들은 상술한 불사들과는 확연한 차이를 보이는데, 불사 내 수많은 건물과 천 여명의 승 려, 그리고 36 개소와 10 개소에 달하는 별원을 가진 대형 사원이었다.

위의 대형불사에는 불탑의 언급이 없는데, 앞서 살펴

41）中國社會科學院考古研究所, 「北魏洛陽永寧寺」, 中國大百科全書 出版社, 1996年, p5 21

42）『續高僧傳』炎一「寶唱傳」, “中院之去大門, 延衰七里. 廊庶相架 檐䨘臨屬. 旁置三十六院, 皆設池台周宇环繞. 千有余偩四事供給”

43）『法苑珠林』卷三十九「感應緣 依道宣律師感應記」, “寺房五重, 并皆七架. 別院大小, 今有十所. 般舟方等二院, 庄嚴最胜. 夏別常有千 人, 四周廊庶, 咸一万間” 
본 남북조불사의 배치경향으로 보아, 중심원락의 기본 배치는 여전히 전탑후전일 가능성이 높다. 형주 하동사 의 경우 이전시기에서 이미 전탑후전 배치가 보이므로, 44) 이를 유지 혹은 계승하였을 가능성도 있다.

하지만, 실제로 불탑이 생략되었거나 불탑이 중심원락 에서 이탈하여 별원에 세워져서 불탑을 언급하지 않았을 가능성도 배제할 수는 없다. 이는 불사 내 불탑과 불전 의 지위가 역전되는 과정, 즉 불탑과 불전의 비중이 엇 비슷하였던 전탑후전 배치에서 불전중심으로 그 비중이 이동하는 과정에서 보이는 현상으로 성당(盛唐) 이후 불 사배치에서 자주 보이는 수법이다. 불탑이 생략된 경우 는 돈황벽화 당대(唐代) 불사벽화에서 자주 보이는데, 이 는 대형불사 내 고층 누각이 크게 발전하여 누각식 탑이 자연스럽게 고층 누각으로 전환된 결과이다. 또 불탑이 별원(別院)에 세워진 경우 역시 장안성을 중심으로 널리 사용되던 수법이며, '동탑원(東塔院)'45), '서탑원(西塔院 )'46), ‘목탑원(木塔院)'47), ‘단탑원(團塔園)'48) 등의 별원 명칭을 통해서 알 수 있다.

남북조 말기 다원식 대형불사는 동위(東魏), 북제(北 齊)시기 조팽성불사(趙彭城佛寺)를 통해서도 확인할 수 있다. 1983년부터 최근까지 이어진 발굴작업을 통하여 방형 해자, 중심탑지, 동남원, 서남원 등이 발견되었다. 방형 해자는 남북 452미터, 동서 434미터로 사원 전체를 둘러싸고 있으며, 해자 이외에 담장은 발견되지 않았다. 중심탑지는 원락의 중심에서 남쪽으로 치우쳐 있는데, 한 변의 길이가 약 30 여 미터인 정방형 평면이다. 탑지 좌우에는 남북으로 길게 뻗은, 너비 8미터 정도의 건물 지가 발견되었다. 불사 동남쪽과 서남쪽에는 한 변이 약 110 여 미터인 정방형 대형원락과 그 안의 전당지가 발견 되었다.49)<Fig.6> 최근 동남원에 대한 정밀 발굴조사가 진행되어,50) 동남원 내부의 모습이 드러났다. 동남원 내 중심에서 북쪽으로 조금 치우친 지점에 동서 36.6미터,

44) 앞서 남조 송시기의 형주 하동사를 언급하였다. 각주 29 참조.

45)『歷代名畫記』灰三「西京寺觀等壁畫壁」千福寺

46)『歷代名畫記』卷三「西京寺觀等壁畫壁」寶應寺

47）『西陽雜组』續集卷五「寺塔記上」長樂坊安國寺

48）『西陽雜祖』續集卷六「寺塔記下」崇仁坊資聖寺

49）中國社會科學院考古研究所河北省文物研究所, 「河北臨漳縣鄴城 遺址東魏北齊佛寺塔基的發現與發掘」, 考古, 2003, 第10期; 中國社會 科學院考古研究所河北省文物研究所, 「河北臨漳縣鄴城遺址趙彭城北 朝佛寺遺址的勘探與發掘」，考古，2010，第7期

50) 중국문물보(中國文物報) 2012년 2월 24일자 기사「2011年度河北 臨漳鄴城遺址趙彭城北朝佛寺發掘」를 통하여, 2011년 10월부터 2012 년 1 월까지 진행된 동남원 정밀발굴 결과를 간략하게 발표하였다.
남북 23.4미터의 장방형 전당지가 있고, 전당지 좌우 양 측 남단에는 전당과 동서 회랑을 연결하는 연결회랑지가 발견되었다. 4 면을 두르고 있는 회랑의 너비는 약 12.5 미 터로 밝혀졌다.

하지만, 최근의 발굴조사에도 불구하고 여전히 여러 가지 의문점이 남는다. 불탑의 북쪽지역에서 전당지가 발견되지 않았으나, 탑지 좌우에 남북으로 길게 뺃은 회 랑형식 건물지로 미루어보아, 전당 또는 기타 부속건물 이 있었을 가능성이 매우 크다. 또 당대(唐代) 다원식 대 형불사의 배치경향51)으로 볼 때, 탑지가 있는 중심원락 양측, 즉 서남원과 동남원의 북쪽에 여러 별원들이 남북 으로 배치되었을 것으로 보인다.

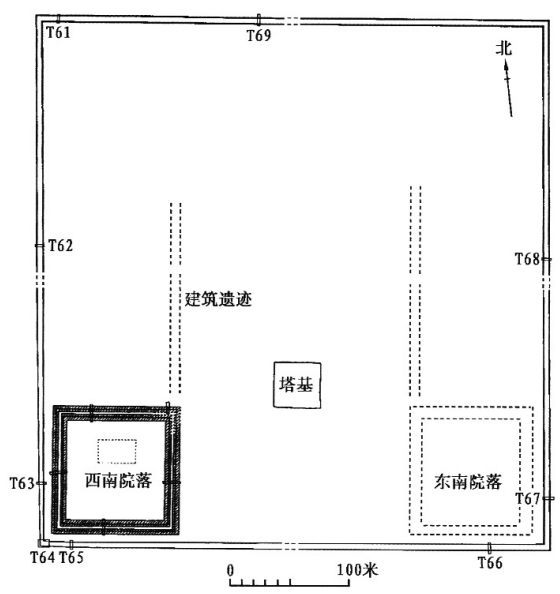

Fig.6 Zhaopengcheng Temple (趙彭城佛 寺) Site (Source: References 24, p32)

한편, 동진(東晉) 불사에서 쌍탑이 처음 출현한 이후, 남북조시기에도 쌍탑배치는 계속되었다. 우선 남조불사의 경우, 송대(宋代)과 양대(梁代)에 걸쳐 차례로 보이는데 다음과 같다.

남조 송(宋) 명제(465-472년 재위)가 저택을 상궁사(湘宮 寺)로 삼았는데, 많은 비용을 들여 매우 사치스러웠다. 효무(452-464년 재위)가 장엄사(莊嚴寺) 탑[刹]을 7층으 로 하였으므로, 송명제는 10 층으로 세우고자 하였다. 하 지만 세울 수 없자, 양 탑[刹]으로 나누어 각각 5층으로 하였다.52)

51) 부희년(傅喜年)은 당대(唐代) 다원식 대형불사를 '랑원식(廊院 式) 배치'로 정의하고 두 가지 유형을 제시하였다. 하나는 '랑외즉소 원(廊外郎小院)', 즉 중심원락 양 옆으로 소원(즉 별원)을 배치하는 경우이고, 다른 하나는 '랑외격항도건소원(廊外隔巷道建小院)', 즉 중 심원락 양 옆에 골목길을 사이에 두고 소원을 배치하는 방법이다. (傅喜年 主編, 『中國古代建築史 第2卷 三國兩晉南北朝隋唐五代建 築』2版, 中國建築工業出版社, 2009, p613 615 참조)

52)『南齊書』卷五十三「良政虞愿傳」, “(宋明)帝以故宅起湘宮寺, 費极奢侈，以孝武庄嚴刹七層，帝欲起十層，不可立，分爲兩刹，各五層” 
보통4년(523년) 9월 15일, 고조가 또 아육왕사에 가서, 무애대회(無碍大會)를 열었다. 두 탑[刹]을 세우고 금앵 (金罌), 차옥앵(次玉罌)이라 이름하였다. 사리 및 손톱, 머리카락을 다시 담아, 탑 안의 칠보탑(七寶塔)에 넣었 다. 또 석함에 보탑을 넣어, 두 탑[刹] 아래 나누어 묻었 다. 53)

이와 같이, 남조불사의 쌍탑배치는 동진(東晉) 시기와 마찬가지로 불사 초창(初創) 당시 계획적인 구획에 의한 것이라기보다는, 당시의 기술적 또는 재정적인 한계에 의하였거나 기존 불사에서 큰 법회의 일환으로 인한 것 임을 추정해 볼 수 있다.

반면에 북조 북위불사의 쌍탑배치는 남조와는 다른 양 상을 보인다. 북위 태화 12 년(488년)에 세워진 『대대탕창 공휘복사비(大代宕昌公暉福寺碑)』에는 다음과 같은 기 록이 있다.

산기상시, 안서장군, 이부내행상서, 탕창공 왕경시이다. $\cdots .$. 이에 정성을 다하여, 고향의 남북 옛 저택에 두 성인[二聖]을 위해 각각 3 층 탑[浮圖]을 지었다.54)

이는 왕경시가 두 성인[二聖], 즉 북위 효문제(孝文帝) 와 문명태후(文明太后)을 위하여 자신의 고향 저택을 내 어 휘복사(暉福寺)로 삼은 내용이다. 이 절은 매우 독특 한 배치를 보이는데, 남북으로 이어진 두 원락에 각각 3 층 탑을 세워, 전체적으로 쌍탑배치의 형식을 취하였다.

이 형식은 북위 운강석굴 제2기(471-494년)55) 굴에서 집중적으로 나타나는 쌍굴(제 $7 \cdot 8$ 굴, 제9·10굴, 제 $1 \cdot 2$ 굴, 제5.6굴, 제3굴)과 매우 유사한 형태를 보인다.<Fig.7> 또한 운강석굴에서 자주 보이는 여러 쌍탑조각도 바로 이 시기에 주로 나타나는 표현이다.56)

53）『梁書』列傳第四十八「諸夷 海南諸國傳」, “至(普通)四年九月十 五日，高租又至寺設無碍大會，堅二刹，各以金齄，次玉罌，重盛舍利及 爪發, 內七宝塔中. 又以石函盛宝塔, 分入兩刹下”

54）『大代宕昌公睴福寺碑』，“散騎常侍, 安西將軍, 吏部內行向書, 宕 昌公, 王慶時. ……乃罄竭丹誠, 於本鄉南北舊宅, 上爲二聖, 造三級浮 圖各一區”(趙一德，「暉福寺碑賞析(并注)」，2005年云岡國際學術研討 會論文集, .文物出版社, 2006, p703 721에서 인용)

55) 운강석굴의 개착(開釸)은 모두 3 시기로 구분한다. 제 1 기는 북위 효성제(孝成帝) 화평초년에서 화평5년(460-464년)이고, 제2기는 북 위황실이 낙양으로 천도하기 전인 효문제(孝文帝) 시기, 즉 471년에 서 494 년이며, 제 3 기는 북위 낙양천도이후 시기, 즉 494년에서 523 년이다. (李裕群, 『古代石窟』, 北京 : 文物出版社, 2003, p139 151 참조)

56) 운강석굴의 쌍탑조각은 주로 제 2 굴 동벽 중층 제 2 감실, 제 5 굴 남벽 명창(明窗) 동측, 제6굴 동서벽 중층 남측 및 남벽, 제 10 굴 전

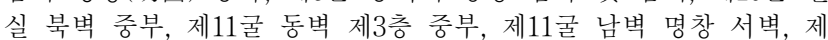
11-9굴 등에서 나타난다. (『中國石窟·云岡石窟一, 二』(北京 : 文物
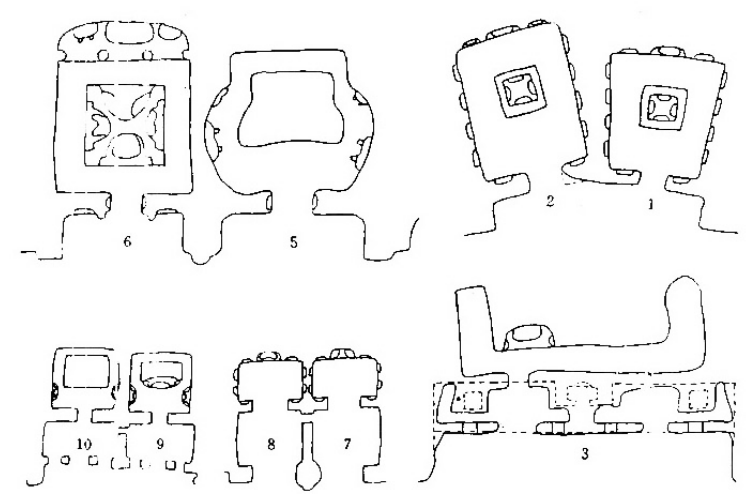

Fig.7 The Type of Twin Grottoes in Yungang Grottoes (Source: Chinese Grottoes · Yungang Grottoes I . Cultural Relics Publishing House, Beijing, 1991, p191)

상술한 바와 같이, 북위 휘복사 및 운강석굴 제2기에 서 보이는 쌍탑, 쌍굴 형식은 모두 “二聖”이라는 북위황 실의 정치적인 배경이 직접적인 원인으로 작용한 것이며, 숙백은 이것을 당시 특정 정치세력의 산물로 규정하고 있다.57)

\section{5. 결 론}

이상으로 후한부터 남북조까지 중국 초기 불교사원의 배치형태를 살펴보았다. 이에 따른 연구 결과는 다음과 같다.

1) 후한(後漢) 삼국(三國)의 불사는 단원식(單院式) 불탑중심 배치를 보인다. 중심 탑과 이를 둘러싸고 있는 회랑식 건물로 구성된 이 형식은 문헌에 나타나는 중국 최초의 불사형식이다. 또한 문헌과 명기(明器)를 통하여 이 중심 탑은 인도의 스투파 요소와 중국의 중층 목조 누각건축이 결합된 형태임을 확인하였는데, 이는 이 시 기 불사제도(佛寺制度)가 아직 인도의 영향에서 완전히 벗어나지 못하였음을 의미하는 것이다.

2) 서진(西晉) 동진(東晉)의 불사는 앞선 시기와 마찬 가지로 단원식 불탑중심 배치를 보인다. 하지만 대략 4 세기 중반 이후부터 불사 내 다양한 건축물이 등장하여, 남북조 불사의 다양한 배치형식을 예고하였다. 그리고

出版社, 1991)의 도판 및 2차례 답사(2007년 8월, 2011년 3월) 사진 참조)

57）宿白，「本城實力的集聚和“云岡模式”的形成与發展」，中國石窟· 云岡石窟 一, 北京：文物出版社, 1991, p192 
동진(東晉)시기에 불사 내 쌍탑이 처음으로 등장하였다.

3) 남북조(南北朝)시기에는 불사 내 건축물의 증가 및 배치의 다양화가 본격적으로 진행되었다. 이에 따라, 여 러 가지 배치형태가 나타났는데, 전탑후전(또는 전탑후 당)이 가장 두드러진 형식이었다. 한편, 이 시기에 나타 나는 쌍탑배치는 그 조성 배경면에서 남조과 북조가 큰 차이를 보이며, 특히 북위불사의 경우 명확한 정치적 배 경에 의하여 조성되었음을 확인하였다.

남북조 말기에 등장한 다원식(多院式) 대형불사에서 중심원락은 여전히 전탑후전 배치를 취하고 있는 것으로 보이는데, 이는 이전시기 단원식 불탑중심 배치에서 수 당시기 다원식 불전중심 배치로의 변화과정에서 나타나 는 과도기적 형식으로 볼 수 있다.

Tab.1 The Layout of Early Chinese Buddhist Temples

\begin{tabular}{|c|c|c|c|}
\hline Temple & Period & $\begin{array}{c}\text { Basic Layout } \\
\text { Form } \\
\end{array}$ & References \\
\hline 白馬寺 & 後漢(67) & Pagoda-centered & 『魏書·釋老志』 \\
\hline 浮圖祠 & $\begin{array}{c}\text { 後漢 } \\
(190-193) \\
\end{array}$ & Pagoda-centered & $\begin{array}{c}\text { 『三國志·吳志·劉繇傳』 } \\
\text { 『後漢書·陶謙傳』 }\end{array}$ \\
\hline $\begin{array}{l}\text { 魏明帝 } \\
\text { 佛寺 } \\
\end{array}$ & $\begin{array}{c}\text { 三國魏 } \\
(227-240) \\
\end{array}$ & Pagoda-centered & 『魏書·釋老志』 \\
\hline 昌樂寺 & $\begin{array}{c}\text { 東晉 } \\
(317-322)\end{array}$ & Twin-pagodas & $\begin{array}{l}\text { 『歷代名畫記』 } \\
\text { 「王廣」 }\end{array}$ \\
\hline 檀溪寺 & $\begin{array}{l}\text { 東晉 } \\
(365)\end{array}$ & Pagoda-centered* & $\begin{array}{l}\text { 『高僧傳』 } \\
\text { 「道安傳」 } \\
\end{array}$ \\
\hline 凌雲精舍 & $\begin{array}{c}\text { 東晉 } \\
(366-371)\end{array}$ & Pagoda-centered* & $\begin{array}{l}\text { 『名僧傳抄』 } \\
\text { 「惠永傳」 }\end{array}$ \\
\hline 東林寺 & $\begin{array}{l}\text { 東晉 } \\
(373)\end{array}$ & Pagoda-centered* & $\begin{array}{l}\text { 『高箇傳』 } \\
\text { 「慧遠傳」 }\end{array}$ \\
\hline 長干寺 & $\begin{array}{c}\text { 東晉 } \\
(373-375) \\
\end{array}$ & Twin-pagodas & $\begin{array}{l}\text { 『高僠傳』 } \\
\text { 「竺慧達傳」 }\end{array}$ \\
\hline 鍾山精舍 & $\begin{array}{c}\text { 南朝宋 } \\
(433)\end{array}$ & $\begin{array}{c}\text { Front Pagoda } \\
\text { and Rear } \\
\text { Buddhist Hall* }\end{array}$ & $\begin{array}{l}\text { 『名僧傳抄』 } \\
\text { 「僧伽羅多囉」 }\end{array}$ \\
\hline 頭陀寺 & $\begin{array}{c}\text { 南朝宋 } \\
(461)\end{array}$ & $\begin{array}{c}\text { Front Pagoda } \\
\text { and Rear } \\
\text { Buddhist Hall* }\end{array}$ & $\begin{array}{c}\text { 『文選』 } \\
「 \text { 頭陀寺碑文」 }\end{array}$ \\
\hline 河東寺 & 南朝宋 & $\begin{array}{l}\text { Front Pagoda } \\
\text { and Rear } \\
\text { Buddhist Hall }\end{array}$ & $\begin{array}{l}\text { 『法苑珠林』「感應緣 } \\
\text { 總述中邊化迹降灵記」 }\end{array}$ \\
\hline 湘宮寺 & $\begin{array}{c}\text { 南朝宋 } \\
(465-472) \\
\end{array}$ & Twin-pagodas & $\begin{array}{c}\text { 『南齊書』 } \\
\ulcorner\text { 良政 虞愿傳」 }\end{array}$ \\
\hline 阿育王寺 & $\begin{array}{c}\text { 南朝梁 } \\
(523)\end{array}$ & Twin-pagodas & $\begin{array}{c}\text { 『梁書』 } \\
「 \text { 諸夷 海南諸國傳」 }\end{array}$ \\
\hline 寶莊嚴寺 & $\begin{array}{c}\text { 南朝梁 } \\
\text { (537) }\end{array}$ & $\begin{array}{c}\text { Front Pagoda } \\
\text { and Rear } \\
\text { Buddhist Hall }\end{array}$ & $\begin{array}{c}\text { 『全唐文』 } \\
\ulcorner 广 \text { 州寶莊嚴寺 } \\
\text { 舍利塔碑」 }\end{array}$ \\
\hline 薄因寺 & 南朝梁 & $\begin{array}{l}\text { Front Pagoda } \\
\text { and Rear } \\
\text { Buddhist Hall }\end{array}$ & $\begin{array}{l}\text { 『續高僧傳』「荊州內 } \\
\text { 華寺釋慧耀傳」 }\end{array}$ \\
\hline
\end{tabular}

\begin{tabular}{|c|c|c|c|}
\hline 大愛敬寺 & 南朝梁 & $\begin{array}{c}\text { Front Pagoda } \\
\text { and Rear } \\
\text { Buddhist Hall* } \\
\text {;Multi-courtyard }\end{array}$ & $\begin{array}{l}\text { 『續高僧傳』 } \\
\text { 「寶唱傳」 }\end{array}$ \\
\hline 河東寺 & 南朝梁 & $\begin{array}{c}\text { Front Pagoda } \\
\text { and Rear } \\
\text { Buddhist Hall* } \\
\text {;Multi-courtyard }\end{array}$ & $\begin{array}{l}\text { 『法苑珠林』「感應緣 } \\
\text { 依道宣律師感應記」 }\end{array}$ \\
\hline $\begin{array}{c}\text { 北魏 } \\
\text { 平城佛寺 }\end{array}$ & $\begin{array}{l}\text { 北魏 } \\
(398)\end{array}$ & $\begin{array}{c}\text { Front Pagoda } \\
\text { and Rear } \\
\text { Buddhist Hall* }\end{array}$ & 『魏書·釋老志』 \\
\hline $\begin{array}{l}\begin{array}{c}\text { 本城 } \\
\text { 永寧寺 }\end{array}\end{array}$ & $\begin{array}{l}\text { 北魏 } \\
\text { (465) }\end{array}$ & Pagoda-centered $*$ & 『魏書·䆁老志』 \\
\hline 思遠佛寺 & $\begin{array}{l}\text { 北魏 } \\
(479)\end{array}$ & $\begin{array}{c}\text { Front Pagoda } \\
\text { and Rear } \\
\text { Buddhist Hall }\end{array}$ & $\begin{array}{l}\ulcorner\text { 大同北魏方山思遠佛 } \\
\text { 寺遺址發掘報告」 }\end{array}$ \\
\hline 思燕佛圖 & $\begin{array}{c}\text { 北魏 } \\
(485-490) *\end{array}$ & $\begin{array}{c}\text { Front Pagoda } \\
\text { and Rear } \\
\text { Buddhist Hall* }\end{array}$ & $\begin{array}{c}\text { 「朝陽北塔 } \\
\text { 考古發掘與維修 } \\
\text { 工程報告」 }\end{array}$ \\
\hline 暉福寺 & $\begin{array}{l}\text { 北魏 } \\
(488) \\
\end{array}$ & Twin-pagodas & $\begin{array}{l}\text { 『大代宕昌公 } \\
\text { 暉福寺碑』 }\end{array}$ \\
\hline $\begin{array}{l}\text { 洛陽 } \\
\text { 永寧寺 }\end{array}$ & $\begin{array}{l}\text { 北魏 } \\
(516)\end{array}$ & $\begin{array}{c}\text { Front Pagoda } \\
\text { and Rear } \\
\text { Buddhist Hall }\end{array}$ & $\begin{array}{c}\text { 『洛陽伽藍記』 } \\
\text { 「永寧寺」; } \\
\text { 『北魏洛陽永寧寺』 }\end{array}$ \\
\hline $\begin{array}{l}\text { 趙彭城 } \\
\text { 佛寺 }\end{array}$ & 東魏北齊 & $\begin{array}{c}\text { Front Pagoda } \\
\text { and Rear } \\
\text { Buddhist Hall } \\
\text {;Multi-courtyard }\end{array}$ & $\begin{array}{c}\ulcorner\text { 河北臨漳縣鄴城遺址 } \\
\text { 趙彭城北朝佛寺遺址的 } \\
\text { 勘探與發掘」 }\end{array}$ \\
\hline
\end{tabular}

마지막으로 본 연구는 문헌위주로 진행된 연구이므로, 그 한계가 드러남은 분명한 사실이다. 그리고 일부 문헌 기록을 통해 당대의 불사배치를 일반화하는 과정에서 귀 납적 오류를 범할 가능성도 배제할 수 없다. 하지만, 중 국 초기 불사배치에 관한 연구가 미진한 상황에서 본 연 구가 동아시아 초기 불사배치 연구의 기초자료로 활용되 기를 기대해 본다.

\section{References}

1. [晋] 陳壽『三國志』

2. [南朝宋] 范曄『後漢書』

3. [北魏] 楊衒之『洛陽伽藍記』

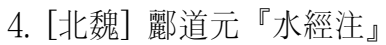

5. [梁] 蕭子顯『南齊書』

6. [梁] 慧晈『高僧傳』

7. [梁] 寶唱『名僧傳抄』

8. [北齊] 魏收『魏書』

9. [唐] 釋道世『法苑珠林』

10. [唐] 釋道宣『續高僧傳』

11. [唐] 張彦遠『歷代名畫記』 
12. Tang Jinyu, 「Excavation on the Restoration of the Han Ritual Architecture in westhern suburbs of the Western Han Dynasty」, Acta Archaeologica Sinica, No. 2, 1959

13. Liang Sicheng, $\ulcorner$ Chinese Buddhist Architecture $\lrcorner$, Journal of Tsinghua University(Science and Technology), Vol. 8, No. 2, 1961

14. Wang Shiren, $\ulcorner$ A Study on the Restoration of the Han Ritual Architecture in southern suburbs of Han Chang'an City $\lrcorner$, Archaeology, No. 9, 1963

15. Kim Sung Woo, $\ulcorner$ The Earliest Pattern of East Asian Buddhist Temples」, Journal of the Architectural Institute of Korea Vol. 3, No. 3, 1987

16. The Institute of Archaeology Chinese Academy of Social Sciences, ${ }^{\mathbb{T}}$ The Yongningsi Temple In Northern Wei Luoyang Excavations in 1979-1994』, The Encyclopedia of China Publishing House, Beijing, 1996

17. Yecheng City Archaeological Team from IA, CASS, and Hebei Provincial Institute of Cultural Relics, $\ulcorner$ Discovery and Excavation of the Pagoda Foundation Vestiges in the Buddhist Temple of the Eastern Qi and Northern Wei period on the Yecheng City-site in Linzhang County, Hebei」, Archaeology, No. 10, 2003

18. Su Bai, $\ulcorner\mathrm{A}$ Study on the Layout of Chinese Buddhist Temples」, (Zhou Shaoliang, 『Fangong: The Art of Chinese Buddhist Architecture』), Shanghai Lexicographical Publishing House, Shanghai, 2006

19. Gansu Provinceial Committee of Cultural Relics, ${ }^{\circledR}$ Essense of Cultural Relics from Gansu», Cultural Relics Publishing House, 2006

20. The Museum of Datong City, 「The Excavation Report on Siyuan Temple of the Northern Wei Dynasty」, Cultural Relics, No. 4, 2007

21. Liaoning Provincial Institute of Cultural Relics, The North Tower Museum of Chaoyang City, "The North Tower of Chaoyang: the report on the archaeological excavation and the maintenance Cultural Relics Publishing House, Beijing, 2007

22. Li Yuqun, 「A Study on the Features of layout and the Causes of the evolution in Chinese Buddhist Temples before the Sui and Tang Dynasties」, Frontier Ethnic Archaeology \& Ethnoarchaeological Studies, Vol. 1, 2009
23. He Liqun, $\ulcorner$ The Research of Buddhist Temples from Northern Dynasty to Sui and Tang Dynasties - Focus on the Evolvement among of Pagoda, Hall and Courtyard」, Study on the Cave Temples, No. 1, Cultural Relics Publishing House, 2010

24. Joint Ye City Archaeological Team of IA, CASS and Hebei Provincial Institute of Cultural Relics, $\ulcorner$ The Exploration and Excavation to the Remains of Buddhist Temple of the Northern Dynasties at Zhaopengcheng, Ye City Site, Linzhang County, Hebei」, Archaeology, No. 7, 2010

25. Xiangfan Municipal Institute of Cultural Relics and Archaeology, $\ulcorner$ A Tomb of the Three Kingdoms Period Excavated in Caiyue, Xiangfan, Hubei」, Cultural Relics, No. 9, 2010

26. Wang Guixiang, $\ulcorner$ An Overview of Buddhist temples in Southern China constructed during the Period of Eastern Jin Dynasty and Southern Dynasties」, Journal of Chinese Architecture History Vol. 6, China Architecture \& Building Press, 2012

27. Wang Guixiang, $\ulcorner$ An Overview of Buddhist temples in Sui and Tang Dynasties」, The International Conference on Bekjae Culture in September 19th 2012, Buyeo National Research Institute of Cultural Heritage

28. Luo Shiping, $\ulcorner$ An Analogy Analysis of The Newly-Excavated Pottery Building Decorated with Xianglun(Xianglun Taolou) and The Hall of Buddha(Futu Ci) of China , Palace Museum Journal, Vol. 162, No. 4, 2012

접수(2012. 12. 14)

수정 (1차: 2013. 2. 24)

게재확정(2013. 2. 25) 